PSYCHOLOGIA ROZWOJOWA, $2017 *$ tom 22 , nr 3, s. 37-55

doi:10.4467/20843879PR.17.015.7575

www.ejournals.eu/Psychologia-Rozwojowa

EWA GURBA

Instytut Psychologii, Uniwersytet Jagielloński, Kraków Institute of Psychology, Jagiellonian University, Kraków e-mail: ewa.gurba@uj.edu.pl

DOROTA CZYŻOWSKA

Instytut Psychologii, Uniwersytet Jagielloński, Kraków Institute of Psychology, Jagiellonian University, Kraków e-mail: d.czyzowska@uj.edu.pl

\title{
Związek kompetencji poznawczych ze stylami tożsamości w różnych okresach rozwojowych
}

\section{The Relationship of Cognitive Competences with Identity Styles in Different Periods of Development}

\begin{abstract}
The article attempts to define the relationship between cognitive competences and identity styles in different periods of life: adolescence, early, middle and late adulthood. It also examines whether there are differences between the age groups in the dominant style of identity and in cognitive competences (formal and post-formal thinking).

The 495 participants: 192 adolescents, 131 young adults, 91 adults and 81 seniors were tested in a baseline study using the Test of Formal Thinking (Horneman, Longeot) and the Identity Styles Questionnaire: ISI-3 (Berzonsky). In an additional pilot study, 281 participants: 166 adolescents, 87 young adults and 28 seniors were tested by means of the "Everyday problems" method (Sebby, Papini).

The results show that early and middle adults in comparison with adolescents revealed a higher level of formal reasoning. In all age groups, the Informational Style of identity prevailed, followed by the Normative and Diffused styles, but with age the level of Commitment and the intensity of the Informational and Normative Style of identity changed.

Among adolescents, there was a negative correlation between TOF scores and Commitment and Normative Style, while a positive but low correlation was found between the level of formal thinking and the level of Commitment in the senior group.

The analysis of the results of the additional study in which the links between the identity styles and the level of post-formal reasoning were tested indicates that there is a stronger correlation compared to the measurement of the relationship between the identity styles and the level of formal thinking in each age group.
\end{abstract}

Key words: identity styles, formal-operational reasoning, post-formal operations, adolescence, early adulthood, middle adulthood, senior age.

Słowa kluczowe: style tożsamości, rozumowanie formalno-operacyjne, operacje postformalne, adolescencja, wczesna dorosłość, średnia dorosłość, wiek senioralny. 


\section{WPROWADZENIE}

Jednym z najtrudniejszych wyzwań, wobec jakich stają ludzie wraz $\mathrm{z}$ dorastaniem, jest adekwatne określanie własnej tożsamości. Adekwatność oznacza tutaj zgodne z rzeczywistością rozpoznanie u siebie zarówno słabych stron, jak i różnorodnych możliwości oraz formułowanie na ich podstawie, planów i celów życiowych.

Proces ten rozgrywa się w kontekście przekonań jednostki i przyjętego systemu wartości oraz indywidualnej historii jej życia. Budowanie tożsamości wymaga zatem refleksji nad różnymi aspektami aktywności jednostki i prowadzi do formułowania odpowiedzi na pytania: kim jestem, dokąd zmierzam, co stanowi o sensie mojego życia. Proces ten zapoczątkowują gwałtowne i wyraźne zmiany w wyglądzie oraz w zachowaniu i relacjach społecznych, których doświadczają nastolatki, a następnie rozciąga się on na kolejne okresy życia przez włączanie i koordynowanie nowych doświadczeń związanych z wypełnianiem funkcji człowieka dorosłego. Adolescenci stają wobec konieczności powiązania różnych, własnych charakterystyk wyłaniających się z wcześniejszych doświadczeń i porównań z innymi osobami (najczęściej rówieśnikami lub idolami) oraz tworzenia przyszłościowych projektów. Dlatego też w tej fazie budowania tożsamości użyteczne jest stosowanie schematów myślenia formalno-operacyjnego, które umożliwiają utworzenie koncepcji własnej osoby w obrębie abstrakcyjnego systemu. Dorośli natomiast, odgrywając różnorodne role społeczne i wchodząc w nowe relacje społeczne, mają szanse odkrywania swoich zdolności i ograniczeń również z perspektywy ocen innych osób. Pomocne mogą być wówczas zdolności relatywistycznego, dialektycznego i zintegrowanego rozumowania. Znaczenie rozwoju poznawczego dla budowania tożsamości dostrzegał zarówno Erik Erikson (1968), jak i Jean Piaget (1972), badacze reprezentujący zdecydowanie odmienne perspektywy teoretyczne. Współcześnie nierozerwalność procesów myślenia i budowania tożsamości jest eksponowana w koncepcji tożsamości narracyjnej Dana P. Mc Adamsa (2001) czy koncepcji stylów tożsamości Michaela Berzonsky’ego (1981). Druga z nich wykorzystana została w prezentowanych badaniach, których celem było prześledzenie udziału kompetencji poznawczych w procesie budowania tożsamości przez adolescentów oraz dorosłych na różnych etapach rozwoju.

Gwałtowne zmiany biologiczne związane $\mathrm{z}$ dojrzewaniem, które obserwują u siebie dorastający, wyzwalają ich pierwsze refleksje nad własną osobą. Nagły wzrost oraz rozwój płciowy powodują zakwestionowanie dotychczasowej tożsamości dziecka i pierwsze próby zmierzenia się z pytaniem: kim jestem wobec doświadczanych zmian (Kroger, 2007). Rozwój poznawczy, który w tym okresie polega na tworzeniu struktur myślenia formalno-operacyjnego, pozwala dorastającemu korzystać z informacji o sobie, pochodzących od znaczących osób, a także porządkować kolejne doświadczenia związane $\mathrm{z}$ różnymi dziedzinami jego aktywności, by następnie dedukować wynikające $\mathrm{z}$ nich charakterystyki własnej osoby. Początkowo wiele trudności przeżywanych przez dorastających w tworzeniu spójnego wizerunku wynika z dużej różnorodności tych doświadczeń i konieczności logicznego ich uporządkowania. Abstrakcyjność myślenia oraz zdolność rozumowania hipotetyczno-dedukcyjnego pozwala nastolatkom na oderwanie się od rzeczywistości w kierunku tego, co możliwe, i definiowanie siebie bardziej w kategoriach tego, co potencjalne, aniżeli aktualne i realne. Zdolność ta umożliwia im formowanie idealnych celów życiowych, które następnie mogą być włączone w koncepcje własnej osoby (Oleszkowicz, Senejko, 2013).

Zdaniem Berzonsky'ego, który opisuje tożsamość zarówno w kategoriach struktury, jak i procesu wykorzystywania zasobów poznawczych w trakcie rozwiązywania problemów życiowych, jednostka może budować tożsamość na różne sposoby, które autor nazywa stylami (ang. identity styles). Styl tożsamości oznacza metody, za pomocą których ludzie konstruują wiedzę o sobie (czyli budują tożsamość) oraz określają rolę, jaką odgrywa ona przy podejmowaniu decyzji życiowych. Autor wyodrębnił trzy style budowania tożsamości (orientacje 
tożsamościowego przetwarzania): informacyjny, normatywny oraz dyfuzyjno-unikowy.

Styl informacyjny oznacza aktywne i samodzielne poszukiwanie informacji o sobie, przetwarzanie, porównywanie $\mathrm{z}$ dotychczasową wiedzą o sobie i ocenianie ich przydatności w kontekście budowania koncepcji siebie (Berzonsky, Ferrari, 1996; Berzonsky, 2003). Dostrzeżenie rozbieżności między osobistymi standardami i posiadaną opinią o sobie a informacjami wynikającymi z nowych doświadczeń staje się czynnikiem motywującym do dalszych poszukiwań. Odmiennie na takie rozbieżności reagują osoby o dominującym stylu normatywnym dążące do podtrzymania dotychczasowego wizerunku. Powstaje on przez przejęcie wzorów postępowania od znaczących dla nich osób, a także odwołanie się do norm rodzinnych, narodowych czy religijnych, które podlegają automatycznej interioryzacji. Głównym celem podejmowanej aktywności jest dla nich ochrona i podtrzymanie posiadanej wizji Ja. Styl dyfuzyjno-unikowy reprezentują osoby, które odsuwają podjęcie decyzji dotyczących problemowych kwestii i ich unikają tak długo, jak to jest możliwe. Osoby o tym stylu tożsamości nie posiadają spójnych przekonań na własny temat, a ich aktywność uwarunkowana jest głównie czynnikami sytuacyjnymi. Berzonsky wskazał, że w trakcie określania własnej tożsamości jednostki mogą różnić się siłą motywacji oraz stabilnością w realizowaniu przyjętego systemu wartości i dążeniu do wybranych celów, co ujął jako zaangażowanie (Berzonsky, 2003).

Zaproponowane przez Berzonsky'ego sposoby budowania tożsamości przez dorastających można umieścić w kontekście opisanego przez Adama Niemczyńskiego (1980) procesu personalizacji działań prowadzącego do wyłonienia się ich indywidualnej podmiotowości. Adolescenci tworzą indywidualny system celów i projektów życiowych, które zwykle nie uwzględniają pragmatyki codzienności czy ograniczeń kontekstu społeczno-kulturowego, a nasycone są idealistycznym spojrzeniem na otaczającą rzeczywistość i własną osobę. Wysoki poziom idealizacji zapewniają schematy myślenia formalno-operacyjnego, które jed- nocześnie zawężają możliwości młodego człowieka w zakresie koordynowania dwóch rzeczywistości: idealnego świata logiki i realnej, otaczającej rzeczywistości. Osobiste projekty, które wyznaczają indywidualność na początkowym etapie budowania tożsamości, mogą być rezultatem samodzielnych poszukiwań (gdy dominuje informacyjny styl tożsamości) lub przejęcia gotowych wzorców od autorytetów (normatywny styl tożsamości). Dominacja dyfuzyjno-unikowego stylu tożsamości wskazywałaby natomiast, że proces personalizacji nie został zainicjowany lub chwilowo jest zawieszony. Pomimo że liczni autorzy wskazują na teoretyczne powiązania między procesem budowania tożsamości a kompetencjami poznawczymi, to w badaniach empirycznych dotyczących tego związku nie uzyskano spójnych wyników (Berzonsky, Weiner, Raphael, 1975; Wagner 1987; Darmody, 1991; Boyes, Chandler, 1992; Krettenauer 2005). Zależności między tymi zmiennymi inaczej się kształtują w zależności od stosowanych wskaźników rozwoju poznawczego. Należy podkreślić, że poszukiwania związków między kompetencjami poznawczymi a sposobami formowania tożsamości dotyczą głównie okresu adolescencji, czyli fazy wyłaniania się tożsamości.

Gdy w badaniach uwzględniany jest rodzaj pozycji epistemicznej ${ }^{1}$ jako wskaźnik rozwoju poznawczego, wówczas pojawiają się określone prawidłowości w związkach między poznaniem a budowaniem tożsamości. Udało się np. wykazać, że dominacji formistycznego stanowiska epistemicznego towarzyszy nasilenie normatywnej orientacji tożsamościowej, a stanowisko konstruktywistyczne ${ }^{2}$ pozytywnie wiązało się $\mathrm{z}$ informacyjną orientacją $\mathrm{w}$ procesie budowania tożsamości (Kramer, 1983; Caputi, Oades, 2001). Odniesienie do innego, bardziej rozwojowego rozróżnienia pozycji epistemicznych na absolutyzm oraz postawę ewaluacyjną ${ }^{3}$ nie pozwala już na określenie tak jednoznacznych zależności. Michael Boyes i Michael Chandler (1992) wyjaśniają słabe korelacje wskaźników rozwoju poznawczego ze sposobami budowania tożsamości wpływem różnic interindywidualnych w zakresie kompetencji poznawczych adolescentów. Interpretacja ta wspierana jest 
wynikami badań Paula Klaczynskiego i Kristen Lavallee (2005), w których takie wskaźniki rozwoju poznawczego, jak poziom myślenia operacyjnego oraz racjonalnego i krytycznego przetwarzania informacji, były analizowane jako predyktory statusów tożsamości. Odmienne rezultaty badań przeprowadzonych przez Tobiasza Krettenauera (2005) wskazują natomiast, że adolescenci pojmujący wiedzę w sposób absolutystyczny (co charakteryzuje nastolatków na początku dorastania, gdy schematy formalno-operacyjne zaczynają się wyłaniać) są bardziej zorientowani na normatywny sposób budowania tożsamości, a reprezentujący postawę ewaluacyjną, przeciwnie, ujawniają głównie informacyjną orientację tożsamościową. Wzorzec tych zależności w dużym stopniu zależał od tego, czy tożsamość opisywana była w kategoriach statusów (Marcia, 1980) czy stylów tożsamości (Berzonsky, 1989).

Ponieważ Berzonsky'emu (Berzonsky, Barclay, 1981), który definiuje style tożsamości jako poznawczo-społeczne procesy przetwarzania informacji dla określenia własnej osoby, nie udało się empirycznie potwierdzić udziału myślenia formalno-operacyjnego, w kolejnych badaniach wykorzystał wskaźniki kompetencji poznawczych wynikające z koncepcji Seymoura Epsteina (Epstein, Pacini, 1999): intuicyjnego (automatycznego) i racjonalnego przetwarzania informacji ${ }^{4}$. W tym wypadku zarówno informacyjny, jak i normatywny styl tożsamości współwystępowały $\mathrm{z}$ rozumowaniem intuicyjnym oraz potrzebą poznawczego domknięcia ${ }^{5}$. Poza tym badani o dużym nasileniu informacyjnego stylu tożsamości charakteryzowali się wysokim, a osoby o stylu normatywnym i dyfuzyjnounikowym, niskim poziomem racjonalnego rozumowania. Adolescenci odznaczający się dużym nasileniem stylu informacyjnego rozstrzygają zatem kwestie tożsamościowe oraz problemy osobiste zarówno w sposób racjonalny, jak i intuicyjny, dzięki czemu potrafią analitycznie, ale i syntetycznie odnosić się do posiadanej wiedzy o sobie i zdobywanych informacji ważnych dla budowania tożsamości. Badani o stylu normatywnym budują koncepcję własnej osoby, wykorzystując głównie system automatycznego myślenia $\mathrm{z}$ obydwiema jego charakterystykami: intuicyjnością rozumowania oraz dążeniem do poznawczego domknięcia, aprobując wartości, normy i wzorce postępowania pochodzące od znaczących dla nich autorytetów. Osoby o dużym nasileniu stylu dyfuzyjno-unikowego natomiast w małym stopniu wykorzystują procesy racjonalnego przetwarzania i nie biorą pod uwagę konsekwencji logicznie wynikających z akceptowanych założeń, a ogniskują się głównie na emocjonalnych rozstrzygnięciach.

Na potrzebę uwzględniania zdolności poznawczych rozumianych jako podejmowanie wysiłku myślenia (Cacioppo et al., 1996) w wyjaśnianiu rozwoju tożsamości zwrócili uwagę David Njus i David Johnson (2008). O zależnościach między kompetencjami poznawczymi a budowaniem tożsamości przez młodzież wnioskowano również z badań zogniskowanych wokół kwestii wyboru wartości w grupie nastolatków. Osoby o bardziej zaawansowanym myśleniu formalno-operacyjnym wyżej cenią wartości bardziej abstrakcyjne, z którymi wiążą się długoterminowe konsekwencje (np. altruizm, niezależność), aniżeli te, które koncentrują się na bezpośredniej gratyfikacji, jak np. wartości hedonistyczne (Darmody, 1991).

\section{ZMIANY W TOŻSAMOŚCI CZLOWIEKA}

Zainicjowany w okresie dorastania proces formowania tożsamości nie kończy się na etapie zdefiniowania przez adolescentów celów i planów życiowych, aczkolwiek przede wszystkim ta faza - wyłaniania się tożsamości - wzbudza największe zainteresowanie wśród badaczy. Koncepcja własnej osoby podlega dalszym modyfikacjom pod wpływem zadań rozwojowych i doświadczeń związanych z odgrywaniem nowych ról społecznych, a także postępującej zmiany rozwojowej w zakresie możliwości poznawczych, którymi dysponuje jednostka na różnych etapach dorosłego życia.

W okresie wczesnej dorosłości kobiety i mężczyźni często zmieniają hierarchię celów i wartości (Harker, Solomon, 1996), które stanowią 
podstawę bardziej realistycznego w porównaniu $\mathrm{z}$ adolescencją, światopoglądu. Tożsamość młodych dorosłych kształtuje się przede wszystkim w kontekście dwóch obszarów doświadczeń: związanych z aktywnością zawodową oraz relacji społecznych, szczególnie w kontaktach intymnych. Wraz z podjęciem aktywności zawodowej poznają swoje możliwości i ograniczenia. Bliskie relacje intymne pozwalają ujrzeć siebie z perspektywy partnera, by następnie podjąć próby koordynacji z własnym punktem widzenia. Realizacja ról pracownika oraz partnera intymnego wymaga podjęcia i wypełniania określonych zobowiązań w kontekście norm i zasad obecnych w konkretnym społeczeństwie, a zatem tożsamość tego okresu stanowi swego rodzaju kompromis między indywidualnymi dążeniami i ograniczeniami oraz oczekiwaniami środowiska społeczno-kulturowego. Skuteczne rozwiązanie problemów związanych z pogodzeniem sprzeczności w obrębie tych dążeń i nacisków wymaga określonych zdolności poznawczych. Zgodnie z koncepcją Piageta (1972) w okresie późnej adolescencji, a nawet wczesnej dorosłości może następować konsolidacja schematów formalno-operacyjnych, zapewniająca jednostce możliwość rozwiązywania różnorodnych problemów przy użyciu myślenia kombinatorycznego oraz indukcyjnego i dedukcyjnego. Jednakże, jak wielokrotnie wykazano, rozumowanie to w małym stopniu przydatne jest do rozwiązywania typowych dla dorosłości codziennych problemów o społecznej naturze (Gurba, 2005; Kallio, 2011). Dlatego też rodzi się pytanie, czy kompetencje w zakresie myślenia formalno-operacyjnego sprzyjają budowaniu tożsamości w okresie dorosłości.

W latach średniej dorosłości tożsamość człowieka nadal może podlegać reorganizacji. Badania wskazują, że rozwojowo bardziej zaawansowane formy tożsamości w sferze aktywności zawodowej często wyłaniają się dopiero w tej fazie życia człowieka, kiedy staje się on ekspertem i osiąga stabilizację w dziedzinie pracy zawodowej. Doświadczeniom pierwszych symptomów starzenia i przemijania towarzyszą nasilenie autorefleksji oraz modyfikacje w koncepcji własnej osoby, dokonywane pod wpływem wiedzy o sobie, czerpanej z doświadczeń związanych z pełnieniem nowych funkcji: eksperta zawodowego, rodzica dorastających dzieci, dorosłego dziecka-opiekuna starzejących się rodziców. Świadomość ograniczeń oraz możliwości w kontekście rozwijanej dotychczas aktywności i realizowanych zamierzeń może sprzyjać podtrzymywaniu zaangażowania jednostki w ich realizację. Na tym etapie kształtowania tożsamości stworzenie spójnego obrazu własnej osoby wymaga oprócz eksploracji nowych charakterystyk związanych z wymienionymi obszarami aktywności również, a może nawet przede wszystkim, uporządkowania ich w obrębie jednego, nadrzędnego systemu Ja, uwzględniającego różnorodność kontekstów, pozostających nieraz we wzajemnej sprzeczności (Oleś, 2011). Dlatego też myślenie formalno-operacyjne może się okazać niewystarczającym narzędziem budowania tożsamości w wieku średnim, tym bardziej że wraz z wiekiem obniżają się kompetencje w zakresie tych zdolności umysłowych (Michalska, 2015).

Wiek senioralny również obfituje w zmiany i wydarzenia, które sprzyjają redefiniowaniu koncepcji własnej osoby. Integracji wymagają aktualnie doświadczane sprzeczności: zakończenie aktywności zawodowej i nasilenie dolegliwości fizycznych oraz działania odsuwane dotychczas z powodu braku czasu, związane $\mathrm{z}$ realizacją zainteresowań czy dostarczające nowych doznań wynikających z pełnienia funkcji babci i dziadka. Poza refleksją wokół aktualnej sytuacji nasilające się u seniorów doświadczenie przemijalności sprzyja charakteryzowaniu własnej osoby w kontekście zdarzeń z przeszłości. Osiągnięcie zintegrowanej tożsamości w wieku senioralnym warunkowane jest przez dokonanie właściwych rozstrzygnięć kryzysów z wcześniejszych okresów życia (Hannah et al. 1996), a także umiejętność poznawczej i emocjonalnej syntezy własnej historii życia z uwzględnieniem osiągnięć i doznanych porażek. Eksploracja w tym okresie ogniskuje się zatem wokół zdarzeń znaczących w życiu seniora i w wypadku tożsamości zintegrowanej prowadzi do zrozumienia i akceptacji historii własnego życia (Erikson, 
1968). Skoro od okresu średniej dorosłości stopniowo, ale systematycznie obniżają się sprawności w zakresie abstrakcyjnego rozumowania (Michalska, 2015; Salthouse, 2009), a jednocześnie wiele osób w późnej dorosłości odznacza się dojrzałymi formami tożsamości, to można wnioskować, że poza formalno-operacyjnymi inne kompetencje poznawcze stanowią użyteczne dla seniora „narzędzie” do konstruowania własnego Ja.

Śledząc zmiany w budowaniu tożsamości przez osoby w różnych fazach życia, można stwierdzić, że:

- w adolescencji człowiek buduje tożsamość, przyjmując głównie perspektywę przyszłościową, eksplorując różnorodne, idealistyczne cele i sposoby ich osiągnięcia;

- we wczesnej dorosłości plany - nadal podstawowy budulec tożsamości - stają się bardziej realistyczne, marzenia okresu dorastania są bowiem modyfikowane pod wpływem własnych doświadczeń i czerpanej z nich wiedzy o sobie;

- w wieku średnim przeobrażenia w koncepcji własnej osoby przebiegają przede wszystkim pod wpływem obecnych doświadczeń i zdobytych osiągnięć;

- dla seniorów tożsamość jest wynikiem integracji znaczących zdarzeń z przeszłości z obecnymi doświadczeniami.

Uwzględniając kompetencje poznawcze charakterystyczne dla każdego okresu dorosłości $\mathrm{i}$ ich znaczenie dla budowania lub rewidowania tożsamości, zauważamy, że:

- nastolatki i młodzi dorośli najsprawniej posługują się myśleniem formalno-operacyjnym, które, stanowiąc podstawę rozumowania hipotetyczno-dedukcyjnego, pozwala na eksplorowanie możliwych wizji własnego życia i zapewnia doświadczenie poczucia pewności odnośnie do trafności dokonanych wyborów, sprzyjając $w$ ten sposób zaangażowaniu w realizację wybranych celów;

- osoby w średniej dorosłości w życiu codziennym rzadziej niż poprzednio stosują myślenie formalno-operacyjne, obok którego lub na podłożu którego (jak twierdzą autorzy postpiagetowskich modeli inteligencji) już u młodych dorosłych wyłaniają się takie cechy rozumowania, jak: jego zintegrowany charakter, kontekstualność, relatywizm, dialektyczność, systemowość, intersystemowość, a także umiejętność formułowania właściwych problemów oraz świadomość istnienia granic systemu naszej wiedzy (Gurba 2011). Te kompetencje poznawcze zdają się odgrywać znaczącą rolę w konstruowaniu tożsamości właśnie w dorosłości, gdyż wówczas konieczna jest umiejętność uwzględniania różnych kontekstów aktywności jednostki, a także należy dokonać integracji jej teraźniejszych doświadczeń: a) z przyszłymi wizjami życia (wczesna dorosłość), b) z pochodzącymi z przeszłości, a także z przyszłymi celami (średnia dorosłość), c) związanych głównie z historią życia jednostki (wiek senioralny).

\section{PROBLEM BADAWCZY}

Uwzględniając wyniki dotychczasowych badań nad zmianami w tożsamości w biegu życia oraz znaczeniem kompetencji poznawczych dla formowania tożsamości, postawiono następujące hipotezy:

1. Najwyższy poziom myślenia formalno-operacyjnego charakteryzuje grupę młodych dorosłych, a najniższy - grupę adolescentów i seniorów.

2. Osoby dorosłe (wczesna, średnia i późna dorosłość) W porównaniu z nastolatkami charakteryzują się większym nasileniem informacyjnego stylu tożsamości oraz zaangażowania, a u seniorów wzrasta nasilenie stylu normatywnego.

3. Istnieje związek między poziomem myślenia formalno-operacyjnego a poszczególnymi stylami tożsamości i zaangażowaniem w grupie adolescentów, w późniejszych okresach związek ten zanika. Oczekuje się, że poziom myślenia formalno-operacyjnego będzie pozytywnie powiązany z poziomem 
informacyjnego, a ujemnie z poziomem normatywnego i dyfuzjno-unikającego stylu tożsamości.

\section{METODA}

\section{Osoby badane}

Aby ustosunkować się do powyższych hipotez, przeprowadzono badania empiryczne, w których uczestniczyło 495 osób, w tym: 192 adolescentów $(M=16$ lat i 2 miesiące), 131 młodych dorosłych $(M=25$ lat $), 91$ osób w średniej dorosłości $(M=46$ lat i 10 miesięcy), 81 seniorów ( $M=66$ lat).

$\mathrm{Z}$ nastolatkami badania przeprowadzano grupowo w czasie lekcji wychowawczej, a z osobami dorosłymi indywidualnie. W zbieraniu materiału badawczego brali udział studenci Instytutu Psychologii UJ.

\section{Narzędzia}

Wykorzystano następujące metody:

1. Kwestionariusz do badania Stylów Tożsamości (ISI-3) Berzonsky’ego w adaptacji Alicji Senejko. Kwestionariusz przeznaczony jest do określenia poziomu zaangażowania oraz trzech stylów tożsamości: informacyjnego, normatywnego i dyfuzyjno-unikowego.

2. Test Operacji Formalnych - TOF autorstwa Horneman, Longeot (Longeot, 1985) skonstruowany na podstawie teorii rozwoju poznawczego Piageta, pozwalający na okre- ślenie, które stadium rozwoju inteligencji (stadium myślenia konkretnego A i B, preformalnego oraz formalnego A i B) reprezentuje osoba badana.

W dodatkowym badaniu pilotażowym, którego celem było określenie związków między myśleniem postformalnym a stylami tożsamości, posłużono się metodą "Codzienne problemy” (Sebby, Papini, 1994) w adaptacji Ewy Gurby i zbadano 281 osób: 166 nastolatków $(M=16$ lat i 1 miesiąc), 87 osób we wczesnej $(M=20$ lat i 9 miesięcy) i 28 w średniej dorosłości $(M=50$ lat i jeden miesiąc).

\section{WYNIKI}

\section{Kompetencje w zakresie myślenia formalno-operacyjnego nastolatków i osób dorosłych}

Aby sprawdzić hipotezę 1, która głosiła, że najwyższy poziom myślenia formalno-operacyjnego charakteryzuje grupę młodych dorosłych, a najniższy - grupę adolescentów i seniorów, obliczono dla każdej grupy wiekowej średni wynik w Teście Operacji Formalnych (TOF). Następnie, z uwagi na to, że rozkład wyników nie spełniał wymogów rozkładu normalnego, przeprowadzono analizy Testem KruskalaWallisa ze względu na wiek jako zmienną grupującą, co pozwoliło sprawdzić, czy poziom myślenia formalno-operacyjnego zmienia się w zależności od wieku badanych, a w kolejnym kroku określono istotność różnic między grupami.

Tabela 1. Statystyki opisowe dla zmiennej zależnej: wynik w Teście Operacji Formalnych (TOF) w poszczególnych grupach wiekowych: Gr. 1 - adolescenci, Gr. 2 - młodzi dorośli, Gr. 3 - osoby w średniej dorosłości, Gr. 4 - seniorzy

\begin{tabular}{|c|c|c|c|c|c|c|c|c|c|c|c|c|}
\hline Zmienna & $\begin{array}{c}\boldsymbol{M} \\
\text { Gr. 1 }\end{array}$ & SD & $\begin{array}{c}\boldsymbol{N} \\
\text { Gr. 1 }\end{array}$ & $\begin{array}{c}\boldsymbol{M} \\
\text { Gr. 2 }\end{array}$ & SD & $\begin{array}{c}\boldsymbol{N} \\
\text { Gr. 2 }\end{array}$ & $\begin{array}{c}\boldsymbol{M} \\
\text { Gr. 3 }\end{array}$ & SD & $\begin{array}{c}\boldsymbol{N} \\
\text { Gr. 3 }\end{array}$ & $\begin{array}{c}\boldsymbol{M} \\
\text { Gr. 4 }\end{array}$ & SD & $\begin{array}{c}\boldsymbol{N} \\
\text { Gr. 4 }\end{array}$ \\
\hline TOF & 17.76 & 4.78 & 192 & 22.76 & 3.49 & 131 & 22.18 & 4.21 & 91 & 18.99 & 5.38 & 81 \\
\hline
\end{tabular}

$N$ - liczba osób, $M$ - średnia, SD - odchylenie standardowe 
Tabela 2. Statystyki opisowe dla zmiennej zależnej: wynik w Teście Operacji Formalnych (TOF) w całej grupie badanych

\begin{tabular}{|c|c|c|c|c|c|}
\hline & $\boldsymbol{N}$ & Średnia & $\begin{array}{c}\text { Odchylenie } \\
\text { standardowe }\end{array}$ & Minimum & Maksimum \\
\hline TOF & 495 & 19.59 & 5.25 & 6.00 & 28.00 \\
\hline
\end{tabular}

$N$ - liczba osób

Tabela 3. Test Kruskala-Wallisa dla zmiennej grupującej: wiek i zmiennej zależnej: poziom TOF

\begin{tabular}{|c|c|}
\hline & TOF \\
\hline Chi-kwadrat & 145.021 \\
\hline Df & 3 \\
\hline Istotność asymptotyczna & $\mathbf{. 0 1}$ \\
\hline
\end{tabular}

Tabela 4. Różnice między poszczególnymi grupami wiekowymi: Gr. 1 - adolescenci, Gr. 2 - młodzi dorośli, Gr. 3 - osoby w średniej dorosłości, Gr. 4 - seniorzy, w średnich zmiennej TOF (Test Operacji Formalnych)

\begin{tabular}{|c|c|c|c|c|c|c|c|c|}
\hline \multirow[t]{2}{*}{ TOF } & \multicolumn{4}{|c|}{$M$} & \multicolumn{4}{|c|}{$p$} \\
\hline & $\begin{array}{c}\text { Gr. } 1 \\
N=192\end{array}$ & $\begin{array}{c}\text { Gr. } 2 \\
N=131\end{array}$ & $\begin{array}{c}\text { Gr. } 3 \\
N=91\end{array}$ & $\begin{array}{c}\text { Gr. } 4 \\
N=81\end{array}$ & Gr. 1 & Gr. 2 & Gr. 3 & Gr. 4 \\
\hline Gr. 1 & & -5.70 & -4.32 & -1.23 & & $<.01$ & $<.01$ & .03 \\
\hline Gr. 2 & 5.70 & & .54 & 3.77 & $<.01$ & & .27 & $<.01$ \\
\hline Gr. 3 & 4.32 & -.54 & & 3.19 & $<.01$ & .27 & & $<.01$ \\
\hline Gr. 4 & 1.23 & -3.77 & -3.19 & & .03 & $<.01$ & $<.01$ & \\
\hline
\end{tabular}

$N$ - liczba osób, $M$ - średnia

W prezentowanym badaniu w Teście Operacji Formalnych (TOF) adolescenci w porównaniu z pozostałymi grupami wiekowymi uzyskali najniższy wynik $(M$ Gr. $1=17.76)$. Mieści się on w dolnej granicy myślenia formalnego. Grupy: młodych dorosłych oraz osób w średniej dorosłości uzyskały w TOF podobne wyniki ( $M$ Gr. $2=22.76$; $M$ Gr. $3=22.18$ ), wskazujące na posługiwanie się przez badanych operacjami formalnymi typu A, ale zbliżającymi się do skonsolidowanych schematów typu B. Młodzi dorośli ( $M$ Gr. 2 = 22.76) oraz osoby w średniej dorosłości $(M$ Gr. $3=22.18)$ w porównaniu z seniorami (18.99) osiągnęły istotnie wyższy rezultat. Jednakże obydwa wyniki wskazują na ten sam poziom myślenia: operacji formalnych typu A.
Hipoteza 1 nie została w pełni potwierdzona, ponieważ okazało się, że młodzi dorośli nie różnią się w poziomie myślenia formalno-operacyjnego od osób w średniej dorosłości, ale obie te grupy prezentują istotnie wyższy poziom myślenia od adolescentów i seniorów.

\section{Modyfikacje w obrębie tożsamości od okresu adolescencji do starości}

Aby sprawdzić hipotezę 2, mówiącą o tym, że osoby dorosłe (wczesna, średnia i późna dorosłość) w porównaniu z nastolatkami charakteryzują się większym nasileniem informacyjnego stylu tożsamości oraz zaangażowania, a u seniorów następuje wzrost nasilenia stylu normatywnego, przeprowadzono analizy Testu 
Kruskala-Wallisa ze względu na wiek jako zmienną grupującą, co pozwoliło sprawdzić, czy nasilenie poszczególnych stylów tożsamości oraz poziom zaangażowania zmienia się w zależności od wieku badanych, a następnie określono istotność różnic między grupami.

Analiza danych wskazuje, że we wszystkich grupach wiekowych dominował informacyjny styl tożsamości, a następnie styl normatywny oraz dyfuzyjno-unikowy oraz że wraz z wiekiem zmienia się poziom zaangażowania i nasilenie informacyjnego oraz normatywnego stylu tożsamości.

Porównanie poziomów stylów tożsamości oraz nasilenia zaangażowania w poszczególnych grupach wiekowych zawierają Tabele: 8 (styl informacyjny), 9 (styl normatywny), 10 (styl dyfuzyjno-unikowy) oraz 11 (zaangażowanie).

Tabela 5. Statystyki opisowe dla zmiennych zależnych: nasilenie stylu informacyjnego, stylu normatywnego, stylu dyfuzyjno-unikowego i poziomu zaangażowania

\begin{tabular}{|l|c|c|c|c|c|}
\hline & $\boldsymbol{N}$ & Średnia & $\begin{array}{c}\text { Odchylenie } \\
\text { standardowe }\end{array}$ & Minimum & Maksimum \\
\hline Zaangażowanie & 495 & 35.91 & 5.56 & 21.00 & 52.00 \\
\hline Styl informacyjny & 495 & 37.24 & 5.75 & 20.00 & 54.00 \\
\hline Styl normatywny & 495 & 31.10 & 5.46 & 17.00 & 49.00 \\
\hline Styl dyfuzyjno-unikowy & 495 & 25.95 & 6.20 & 8.00 & 44.00 \\
\hline
\end{tabular}

Tabela 6. Test Kruskala-Wallisa dla zmiennej grupującej: wiek i zmiennych zależnych: nasilenie stylu informacyjnego, stylu normatywnego, stylu dyfuzyjno-unikowego i poziomu zaangażowania

\begin{tabular}{|l|c|c|c|c|}
\hline & Zaangażowanie & $\begin{array}{c}\text { Styl } \\
\text { informacyjny }\end{array}$ & $\begin{array}{c}\text { Styl } \\
\text { normatywny }\end{array}$ & $\begin{array}{c}\text { Styl } \\
\text { dyfuzyjno-unikowy }\end{array}$ \\
\hline Chi-kwadrat & 39.93 & 39.37 & 54.26 & 1.30 \\
\hline Df & 3 & 3 & 3 & 3 \\
\hline Istotność asymptotyczna & $<.01$ & $<.01$ & $<.01$ & .730 \\
\hline
\end{tabular}

Tabela 7. Statystyki opisowe dla zmiennej: poziom stylu tożsamości (informacyjny, normatywny, dyfuzyjno-unikowy) oraz zaangażowanie w poszczególnych grupach wiekowych: Gr. 1 - adolescenci, Gr. 2 - młodzi dorośli, Gr. 3 - średnia dorosłość, Gr. 4 - seniorzy

\begin{tabular}{|l|c|c|c|c|c|c|c|c|c|c|c|c|}
\hline Zmienna & $\begin{array}{c}\boldsymbol{M} \\
\text { Gr. 1 }\end{array}$ & SD & $\begin{array}{c}\boldsymbol{N} \\
\text { Gr. 1 }\end{array}$ & $\begin{array}{c}\boldsymbol{M} \\
\text { Gr. 2 }\end{array}$ & SD & $\begin{array}{c}\boldsymbol{N} \\
\text { Gr. 2 }\end{array}$ & $\begin{array}{c}\boldsymbol{M} \\
\text { Gr. 3 }\end{array}$ & SD & $\begin{array}{c}\boldsymbol{N} \\
\text { Gr. 3 }\end{array}$ & $\begin{array}{c}\boldsymbol{M} \\
\text { Gr. 4 }\end{array}$ & SD & $\begin{array}{c}\boldsymbol{N} \\
\text { Gr. 4 }\end{array}$ \\
\hline $\begin{array}{l}\text { Zaanga- } \\
\text { żowanie }\end{array}$ & 34.76 & 4.49 & 192 & 36.81 & 5.56 & 131 & 37.35 & 5.56 & 91 & 37.03 & 5.49 & 81 \\
\hline St. inform. & 35.22 & 5.07 & 192 & 37.93 & 5.07 & 131 & 37.65 & 5.18 & 91 & 40.26 & 6.25 & 81 \\
\hline St. norm. & 30.04 & 5.40 & 192 & 30.18 & 5.30 & 131 & 31.48 & 5.01 & 91 & 35.14 & 4.61 & 81 \\
\hline St. dyfuz. & 25.79 & 5.73 & 192 & 25.85 & 5.45 & 131 & 25.26 & 6.51 & 91 & 26.56 & 6.92 & 81 \\
\hline
\end{tabular}

$N$ - liczba osób, $M$ - średnia, SD - odchylenie standardowe 
Tabela 8. Różnice między grupami wiekowymi w średnich: poziom stylu informacyjnego

\begin{tabular}{|c|c|c|c|c|c|c|c|c|}
\hline $\begin{array}{l}\text { Styl } \\
\text { informacyjny }\end{array}$ & \multicolumn{4}{|c|}{$M$} & \multicolumn{4}{|c|}{$p$} \\
\hline & $\begin{array}{c}\text { Gr. } 1 \\
N=192\end{array}$ & $\begin{array}{c}\text { Gr. } 2 \\
N=131\end{array}$ & $\begin{array}{c}\text { Gr. } 3 \\
N=91\end{array}$ & $\begin{array}{c}\text { Gr. } 4 \\
N=81\end{array}$ & Gr. 1 & Gr. 2 & Gr. 3 & Gr. 4 \\
\hline Gr. 1 & & -2.71 & -2.59 & 2.27 & & $<.01$ & $<.01$ & $<.01$ \\
\hline Gr. 2 & 2.27 & & .29 & -2.32 & $<.01$ & & .68 & $<.01$ \\
\hline Gr. 3 & 2.39 & .29 & & -2.61 & $<.01$ & .68 & & $<.01$ \\
\hline Gr. 4 & -2.27 & 2.32 & 2.61 & & $<.01$ & $<.01$ & $<.01$ & $<.01$ \\
\hline
\end{tabular}

Tabela 9. Różnice w średnich: poziom stylu normatywnego między grupami wiekowymi

\begin{tabular}{|c|c|c|c|c|c|c|c|c|}
\hline \multirow{2}{*}{$\begin{array}{c}\text { Styl } \\
\text { normatywny }\end{array}$} & \multicolumn{4}{|c|}{$M$} & \multicolumn{4}{|c|}{$p$} \\
\hline & $\begin{array}{c}\text { Gr. } 1 \\
N=192\end{array}$ & $\begin{array}{c}\text { Gr. } 2 \\
N=131\end{array}$ & $\begin{array}{c}\text { Gr. } 3 \\
N=91\end{array}$ & $\begin{array}{c}\text { Gr. } 4 \\
N=81\end{array}$ & Gr. 1 & Gr. 2 & Gr. 3 & Gr. 4 \\
\hline Gr. 1 & & -.4 & -2.43 & -5.04 & & .80 & .01 & $<.01$ \\
\hline Gr. 2 & .4 & & -2.30 & -4.76 & .8 & & .07 & $<.001$ \\
\hline Gr. 3 & 2.43 & 2.30 & & -3.66 & $<.01$ & .07 & & $<.01$ \\
\hline Gr. 4 & 5.04 & 4.74 & 3.66 & & $>.01$ & $>.01$ & $<.01$ & \\
\hline
\end{tabular}

Tabela 10. Różnice między grupami wiekowymi w średnich: poziom stylu dyfuzyjno-unikowego

\begin{tabular}{|l|c|c|c|c|c|c|c|c|}
\hline $\begin{array}{c}\text { Styl } \\
\text { dyfuzyjno-unikowy }\end{array}$ & \multicolumn{4}{|c|}{ Różnice między średnimi } & \multicolumn{5}{c|}{$p$} \\
\hline & $\begin{array}{c}\text { Gr. 1 } \\
N=192\end{array}$ & $\begin{array}{c}\text { Gr. 2 } \\
N=131\end{array}$ & $\begin{array}{c}\text { Gr. 3 } \\
N=91\end{array}$ & $\begin{array}{c}\text { Gr. } 4 \\
N=81\end{array}$ & Gr. 1 & Gr. 2 & Gr. 3 & Gr. 4 \\
\hline Gr. 1 & & -.6 & .54 & .77 & & .9 & .42 & .24 \\
\hline Gr. 2 & .6 & & .59 & -.72 & .9 & & .45 & .4 \\
\hline Gr. 3 & -.54 & -.59 & & 1.31 & .43 & .45 & & .19 \\
\hline Gr. 4 & -.77 & .72 & -1.31 & & .24 & .4 & .19 & \\
\hline
\end{tabular}

Tabela 11. Różnice między grupami wiekowymi w średnich: poziom zaangażowania

\begin{tabular}{|l|c|c|c|c|c|c|c|c|}
\hline Zaangażowanie & \multicolumn{4}{|c|}{ Różnice między średnimi } & \multicolumn{5}{c|}{$p$} \\
& Gr. 1 & Gr. 2 & Gr. 3 & Gr. 4 & Gr. 1 & Gr. 2 & Gr. 3 & Gr. 4 \\
\hline Gr. 1 & & -1.05 & -2.79 & -2.27 & & $<.01$ & $<.01$ & $<.01$ \\
\hline Gr. 2 & $\mathbf{1 . 0 5}$ & & -.54 & -.22 & $<.01$ & & .46 & .07 \\
\hline Gr. 3 & $\mathbf{2 . 7 9}$ & & & .32 & $<.01$ & .46 & & .69 \\
\hline Gr. 4 & $\mathbf{2 . 2 7}$ & .22 & -.32 & & $<.01$ & .07 & .69 & \\
\hline
\end{tabular}


Porównując nasilenie poszczególnych stylów tożsamości i poziom zaangażowania między badanymi grupami, stwierdzamy, że nasilenie informacyjnego stylu tożsamości (Tabela 8) wzrasta wraz z wiekiem, a seniorzy w porównaniu z pozostałymi grupami wiekowymi uzyskali wynik najwyższy $(M$ Gr. 4 = 40.26). Grupy młodych dorosłych $(M$ Gr. 2 = 37.93) i osób w średniej dorosłości $(M$ Gr. $3=37.65)$ reprezentowały podobne nasilenie tego stylu tożsamości, ale istotnie wyższe od adolescentów ( $M$ Gr. $1=35.22)$. W odniesieniu do normatywnego stylu tożsamości (Tabela 9) zaobserwowano ogólny trend rozwojowy, jednakże istotny dopiero od okresu średniej dorosłości ( $M$ Gr. $3=31.48$ ). Najwyższy wynik charakteryzuje seniorów ( $M$ Gr. $4=35.14)$, najniższy nastolatków $(M$ Gr. $1=30.04)$ i porównywalny z nim młodych dorosłych ( $M$ Gr. $2=30.18)$. W porównywanych grupach nie zanotowano natomiast istotnych różnic w nasileniu dyfuzyjno-unikowego stylu tożsamości (Tabela 10).

Nasilenie zaangażowania w badanych grupach (Tabela 11) wzrasta od okresu adolescencji ( $M$ Gr. $1=34.76, M$ Gr. 2 = 36.81) do wczesnej dorosłości i na porównywalnym poziomie utrzymuje się do późnej dorosłości ( $M$ Gr. $3=37.35$, $M$ Gr. 4 = 37.03). W świetle uzyskanych wyników stwierdzić należy, że Hipoteza 2 została zweryfikowana.

\section{Związek myślenia operacyjnego ze stylami tożsamości}

Aby sprawdzić podstawową dla niniejszych rozważań hipotezę o związku między poziomem myślenia formalno-operacyjnego a poszczególnymi stylami tożsamości i zaangażowaniem przeprowadzono analizę korelacji r-Spearmana oddzielnie dla poszczególnych grup wiekowych (Tabela 12).

Jedynie w dwóch grupach wiekowych: adolescentów i seniorów wystąpiły istotne statystycznie korelacje między poziomem operacji formalnych a stylami tożsamości. W grupie nastolatków odnotowujemy ujemne zależności między wynikiem w Teście Operacji Formalnych (TOF) a nasileniem stylu normatywnego $(r=-.21)$ oraz zaangażowania $(r=-.25)$, a $\mathrm{w}$ grupie seniorów pozytywna zależność dotyczy wyniku w TOF i nasilenia zaangażowania $(r=.24)$. Hipoteza 3 nie znalazła zatem pełnego potwierdzenia w świetle uzyskanych wyników.

Myślenie formalno-operacyjne nie wyczerpuje kompetencji poznawczych człowieka dorosłego, a nawet, jak wynika $\mathrm{z}$ badań autorów modeli inteligencji postpiagetowskich i neopiagetowskich, zmniejsza się znaczenie operacji formalnych w trakcie rozwiązywania praktycznych, codziennych problemów człowieka dorosłego. Poza tym, jak wskazano we wprowadzeniu, w różnych okresach dorosłości rozumowanie kontekstualne, relatywistyczne, dialektyczne $\mathrm{i}$ zintegrowane $\mathrm{w}$ porównaniu $\mathrm{z}$ abstrakcyjnym

Tabela 12. Współczynniki korelacji r-Spearmana zmiennych: TOF i style tożsamości oraz zaangażowanie w poszczególnych grupach wiekowych

\begin{tabular}{|l|c|c|c|c|c|c|}
\hline \multicolumn{1}{|c|}{ Grupa } & Zmienna & $\begin{array}{c}\text { Styl } \\
\text { informacyjny }\end{array}$ & $\begin{array}{c}\text { Styl } \\
\text { normatywny }\end{array}$ & $\begin{array}{c}\text { Styl dyfuzyjno- } \\
- \text {-unikowy }\end{array}$ & Zaangażowanie & $\mathrm{N}$ \\
\hline 1. Adolescencja & TOF & -.08 & -.21 & -.02 & -.25 & 192 \\
\hline $\begin{array}{l}\text { 2. Wczesna } \\
\text { dorosłość }\end{array}$ & TOF & .09 & -.02 & -.02 & .16 & 131 \\
\hline $\begin{array}{l}\text { 3. Średnia } \\
\text { Dorosłość }\end{array}$ & TOF & -.01 & -.00 & -.01 & .18 & 91 \\
\hline $\begin{array}{l}\text { 4. Późna dorosłość } \\
\text { (seniorzy) }\end{array}$ & TOF & -.10 & -.19 & -.15 &. $\mathbf{2 4}$ & 81 \\
\hline
\end{tabular}

Uwaga: Pogrubioną czcionką oznaczono korelacje istotne statystycznie. 
myśleniem formalno-operacyjnym zdaje się bardziej użyteczne $\mathrm{w}$ procesie redefiniowania tożsamości, na podstawie obecnych i przeszłych doświadczeń związanych z pełnieniem różnorodnych funkcji społecznych. Dlatego podjęto próby, na razie pilotażowe, sprawdzenia znaczenia myślenia postformalnego dla poszczególnych stylów tożsamości i zaangażowania od adolescencji do późnej dorosłości.

Przyjęto hipotezę mówiącą, że myślenie postformalne: relatywistyczne, dialektyczne, kontekstualne i zintegrowane, sprzyja osiąganiu dojrzałej tożsamości u osób dorosłych.

W kontekście tej hipotezy podjęto dodatkowe badanie osób od adolescencji do średniej dorosłości, wykorzystując oprócz omawianego powyżej Kwestionariusza do Badania Stylów Tożsamości Berzonsky'ego, metodę do określenia poziomu myślenia postformalnego „Codzienne problemy”, która opiera się na założeniach koncepcji Labouvie-Vief (Sebby, Papini, 1994). Metoda ta składa się z trzech dylematów zawierających sytuacje problemowe typowe dla adolescentów, osób w średniej i późnej dorosłości. Labouvie-Vief wyróżniła cztery rodzaje autoregulacji i związane z nimi schematy umysłowe, obecne na różnych etapach rozwoju Ja. Wyznaczają one poziomy rozwojowe: presystemowy, intrasystemowy, intersystemowy i autonomiczny, czyli zintegrowany. Poziom presystemowy opisuje typowe dla aktywności dziecka regulacje sensomotoryczne, schematy wyobrażeniowe i operacje konkretne, które stanowią elementy struktury Ja, pozbawionej jeszcze nadrzędnego systemu zarządzającego. Poziom regulacji intrasystemowych (symbolicznych) obejmuje operacje formalne. Poziom regulacji intersystemowych tworzą operacje postformalne, które pozwalają ujmować rzeczywistość i logikę jako odrębne, ale równoważne systemy. Na tym poziomie rozwija się tzw. dualistyczne rozumienie prawdy, które wiąże się z możliwością dokonywania w zależności od uwzględnianego kontekstu odmiennych ocen analizowanego zjawiska. Poznanie rzeczywistości opiera się na logicznym relatywizmie i wiąże się z umiejętnością dostrzegania różnorodnych, właściwych dla danej sytuacji, rozwiązań, przy jednoczesnym zachwianiu poczucia pewności odnośnie do posiadanej wiedzy. Regulacje z poziomu autonomicznego (myślenia zintegrowanego) reprezentują najwyższy poziom rozwoju. Podstawowym regulatorem jest struktura Ja, która pełni funkcję nadrzędnego metasystemu. Integruje ona trzy sfery aktywności człowieka: myślenie, emocje i działanie. W wyniku tego aktywność jednostki postrzegana jest jako wynik dążeń jednostki, wyznaczanych przez nią celów i wartości (Gurba, 2005, 2013).

\section{Osoby badane}

Na obecnym etapie badań określono nasilenie poszczególnych stylów tożsamości i zaangażowania oraz poziom myślenia postformalnego u 166 adolescentów (średnia wieku $=16.1$ ), 87 młodych dorosłych (średnia wieku $=20.9$ ) i 28 osób w średniej dorosłości (średnia wieku = 50.1), a następnie policzono współczynniki korelacji Spearmana dla tych zmiennych. Uzyskane wyniki prezentuje Tabela 13.

Tabela 13. Współczynniki korelacji r-Spearmana między zmiennymi: style tożsamości i zaangażowanie a wskaźniki poziomu rozumowania postformalnego w teście „Codzienne problemy”

\begin{tabular}{|l|c|c|c|c|c|c|}
\hline \multicolumn{1}{|c|}{ Zmienna } & $\begin{array}{c}\text { Myślenie } \\
\text { postformalne } \\
r \text { Gr. 1 }\end{array}$ & $\begin{array}{c}N \\
\text { Gr. 1 }\end{array}$ & $\begin{array}{c}\text { Myślenie } \\
\text { postformalne } \\
r \text { Gr. 2 }\end{array}$ & $\begin{array}{c}N \\
\text { Gr. 2 }\end{array}$ & $\begin{array}{c}\text { Myślenie } \\
\text { postformalne } \\
r \text { Gr. 3 }\end{array}$ & $\begin{array}{c}N \\
\text { Gr. 3 }\end{array}$ \\
\hline St. informacyjny & .01 & 166 &. $\mathbf{2 4}$ & 87 & $\mathbf{. 5 2}$ & 28 \\
\hline St. normatywny & .01 & 166 & .15 & 87 & .25 & 28 \\
\hline $\begin{array}{l}\text { St. dyfuzyjno- } \\
\text {-unikowy }\end{array}$ & .13 & 166 & -.25 & 87 & -.06 & 28 \\
\hline Zaangażowanie & $\mathbf{- . 1 8}$ & 166 & $\mathbf{. 2 3}$ & 87 & $\mathbf{. 4 8}$ & 28 \\
\hline
\end{tabular}

Oznaczenia: Gr. 1 - adolescencja, Gr. 2 -wczesna dorosłość, Gr. 3 - średnia dorosłość.

Pogrubioną czcionką oznaczono korelacje istotne statystycznie. 
Analiza wyników wskazuje na ujemny, ale słaby związek między nasileniem zaangażowania a poziomem rozumowania postformalnego w grupie adolescentów $(r=-.18)$ i pozytywny związek między tymi zmiennymi w grupie młodych dorosłych $(r=.23)$ oraz dość silny związek w średniej dorosłości $(r=.48)$. Informacyjny styl tożsamości pozytywnie powiązany jest z poziomem myślenia postformalnego u młodych dorosłych $(r=.24)$ i zależność ta wyraźnie wzrasta w grupie osób w średniej dorosłości $(r=.52)$. Styl dyfuzyjno-unikowy okazuje się ujemnie skorelowany z poziomem myślenia postformalnego $\mathrm{w}$ grupie młodych dorosłych $(r=-.25)$.

\section{DYSKUSJA}

Jak wynika z zamieszczonego we wstępie przeglądu literatury, badaczom nie udało się uzyskać spójnych wyników, jednoznacznie wskazujących na występowanie związków między poziomem myślenia formalno-operacyjnego a stylami tożsamości, przy czym należy zaznaczyć, że eksploracje dotyczyły głównie adolescentów, którzy są na początku drogi budowania tożsamości. $Z$ tych powodów podjęto badania, w których oprócz dorastających uczestniczyły również osoby we wczesnej, średniej i późnej dorosłości.

\section{Myślenie formalno-operacyjne nastolatków i osób dorosłych}

Biorąc pod uwagę wyniki dotychczasowych badań nad inteligencją skrystalizowaną i płynną (zdolności formalnego rozumowania można zakwalifikować do tej drugiej) oraz dotyczące rozwiązywania sylogizmów przez dorosłych (Olejnik, 2011; Gurba, 1995; Michalska, 2015; Salthouse, 2009), oczekiwano u młodych dorosłych i tych będących w średniej dorosłości ujawnienia się najwyższego poziomu sprawności w zakresie posługiwania się operacjami formalnymi, a najniższego u nastolatków i seniorów (Hipoteza 1). Hipoteza ta potwierdziła się w grupie badanych przez nas osób. Porównanie wyników TOF pozwala rozpoznać krzywoliniową zależność poziomu myślenia formalno-operacyjnego od wieku badanych. Poziom wykonania zadań w Teście Operacji Formalnych rośnie od adolescencji do wczesnej dorosłości, w średniej dorosłości następuje stabilizacja, a obniża się w grupie seniorów. Warto jednak zauważyć, że średni wynik seniorów jest istotnie wyższy od uzyskanego przez nastolatków. Adolescenci ujawnili najmniejszą biegłość w posługiwaniu się operacjami formalnymi, otrzymując wyniki wskazujące na początki opanowania tej zdolności. Znacząca poprawa w rozwiązywaniu zadań TOF przez młodych dorosłych, których rezultaty mieszczą się w górnej granicy przedziału operacji formalnych A, świadczy o zbliżaniu się tych osób do osiągnięcia zdolności posługiwania się operacjami typu B (ponad $60 \%$ osób z tej grupy ujawniło tę umiejętność). Odnotowaną zmianę rozwojową w porównaniu $\mathrm{z}$ okresem adolescencji można łączyć z postępującymi w fazie wyłaniającej się dorosłości (emerging adulthood) procesami dojrzewania mózgu, szczególnie płatów czołowych i doskonaleniem się funkcji wykonawczych (Gurba, 2011, 2013), aczkolwiek należy pamiętać o innych, ważnych uwarunkowaniach rozwoju poznawczego (Michalska, 2015).

Zaobserwowany w prezentowanych badaniach własnych spadek kompetencji poznawczych w zakresie myślenia formalno-operacyjnego między średnią a późną dorosłością dobrze udokumentowany jest $\mathrm{w}$ literaturze przedmiotu, chociaż nadal poszukiwane są mechanizmy leżące u jego podłoża. Wymienia się następujące źródła obniżenia tej sprawności:

- spowolnienie procesów przetwarzania informacji, spadek pojemności pamięci operacyjnej, co wiąże się z biologicznym deficytem procesów hamowania;

- mała ekologiczna wartość testów do pomiaru abstrakcyjnego myślenia formalno-operacyjnego;

- obniżona u seniorów w porównaniu z osobami młodszymi motywacja osiągnięć w zakresie rozwiązywania akademickich testów inteligencji (Salthouse, 2009; Michalska, 2015). 


\section{Zmiany w stylach tożsamości i zaangażowaniu od adolescencji po wiek senioralny}

Przystępując do badań nad stylami tożsamości osób w różnych okresach życia od adolescencji do późnej dorosłości, oczekiwano, że osoby dorosłe $\mathrm{z}$ uwagi na szerszy $\mathrm{w}$ porównaniu z nastolatkami zakres doświadczeń i możliwości zdobywania wiedzy o sobie w trakcie pełnienia różnorodnych funkcji, charakteryzują się większym aniżeli adolescenci nasileniem informacyjnego stylu tożsamości. Poza tym zakładano również, że w dorosłości wzrasta poziom zaangażowania, ponieważ budowanie spójnej koncepcji siebie przez określenie i akceptację konkretnych celów życiowych związanych z zadaniami rozwojowymi może sprzyjać angażowaniu się w ich realizację.

Wyniki badań prezentowanych w tym opracowaniu potwierdzają wskazane przypuszczenia (Hipoteza 2). Od okresu adolescencji do późnej dorosłości, poza stabilizacją między wczesną a średnią dorosłością, systematycznie wzrasta nasilenie informacyjnego stylu tożsamości. Młodzi ludzie, gdy wchodzą w dorosłość, stają wobec możliwości zdobywania doświadczeń związanych z odgrywaniem nowych ról społecznych: rodzinnych (współmałżonka, rodzica, dorosłego dziecka starzejących się rodziców) oraz zawodowych. Jednocześnie stopień realizacji obowiązków wynikających z tych ról pozwala weryfikować budowaną koncepcję własnej osoby i, jak pokazują rezultaty badania, dorośli z możliwości tych korzystają, odznaczając się wzrastającą samodzielnością w konstruowaniu tożsamości. Role społeczne nabywane we wczesnej dorosłości są kontynuowane (aczkolwiek w zmodyfikowany sposób) w kolejnym okresie rozwojowym, a więc osoby czerpią ze zdobytego już doświadczenia oraz wynikającej z niego wiedzy o sobie, czym można wyjaśnić rozpoznaną w naszym badaniu stabilizację poziomu informacyjnego stylu tożsamości. Radykalnie nowe wymagania stawiane są natomiast przed seniorami: zwykle pogarsza się ich kondycja fizyczna, modyfikacji podlegają pozycje i role zarówno w rodzinie, jak i w społeczeństwie. Do właściwego ich wy- pełniania konieczne jest posiadanie adekwatnej wiedzy o sobie - człowieku starzejącym się a jednocześnie wiedza ta nabywana jest i może być rewidowana w trakcie realizowania nowych ról: dziadka, emeryta, wdowy. Zmiany te mogą stanowić okazję do wzrostu poziomu stylu informacyjnego, co zaobserwowano między średnią a późną dorosłością.

Podwyższenie normatywnego stylu tożsamości odnotowano w okresie między adolescencją a średnią dorosłością i wiekiem senioralnym oraz między wczesną a późną dorosłością. Najmniejsze nasilenie tego stylu tożsamości w adolescencji można zrozumieć w kontekście krytycyzmu i związanego z nim buntu młodzieńczego kierowanego wobec różnych autorytetów. Największe nasilenie normatywnego stylu u osób w wieku senioralnym wiąże się natomiast ze zjawiskiem obniżania się samooceny ludzi starych i towarzyszącym mu wzroście zachowań konformistycznych u części seniorów (Staudinger, Bluck, Herzberg, 2003). Nasilenie normatywnego stylu tożsamości u osób starszych może również świadczyć o charakterystykach związanych z przynależnością do określonej kohorty. Warto zwrócić bowiem uwagę, że warunki, w jakich dojrzewali i wchodzili w dorosłość obecni seniorzy, kontekst społeczno-kulturowy, w jakim oni funkcjonowali, dość istotnie różnił się od tego, w jakim żyją obecnie nastolatki i młodzi dorośli. Możliwości swobodnego eksplorowania i wypracowywania własnej tożsamości w okresie ich młodości, przypadającej na lata 50. i 60. ubiegłego wieku, były znacznie mniejsze przy jednocześnie większym nacisku na budowanie koncepcji siebie na podstawie gotowych wzorców i autorytetów, co mogło znaleźć odzwierciedlenie w częstszym budowaniu normatywnego stylu tożsamości.

Nasilenie czynnika zwanego zaangażowaniem, które Berzonsky (2003) definiuje jako siłę motywacji oraz stabilność w realizowaniu przyjętego systemu wartości i dążeniu do wybranych celów, zmienia się zgodnie z założonym kierunkiem. Nasilenie zaangażowania systematycznie wzrasta od okresu adolescencji do wieku senioralnego. Najniższy poziom zaangażowania odnotowany w przypadku nastolatków obrazuje sytuację moratorium - dorastający eksplorują 
różne opcje życia i własnego w nim miejsca, sprawdzając idealistyczne nieraz wizje, poprzez eksperymentowanie i podejmowanie różnych form aktywności. Zdaniem Jeffreya Arnetta (2000) taki stan tożsamości może się jeszcze utrzymywać w fazie wyłaniającej się dorosłości, a więc u dwudziestokilkulatków. Podjęcie nowych ról społecznych wraz z wynikającą z nich odpowiedzialnością za drugą osobę (współmałżonka, dziecko, pracownika), a także wyznaczenie konkretnych celów życiowych sprzyja wzrostowi stabilności działań i motywacji do ich osiągnięcia, co w konsekwencji prowadzi do rozwoju autonomii jednostki (Obuchowski, 1977).

\section{Związek kompetencji poznawczych i stylów tożsamości w okresie adolescencji i dorosłości}

Odwołując się do koncepcji stylów tożsamości Berzonsky'ego, mówiącej, że styl tożsamości oznacza metody, za pomocą których ludzie konstruują wiedzę o sobie (czyli budują tożsamość), oraz określa funkcję, jaką pełni ona przy podejmowaniu decyzji życiowych (Berzonsky, Ferrari, 1996), można oczekiwać istnienia zależności między stylami tożsamości i zaangażowaniem a kompetencjami poznawczymi.

Główna testowana w badaniach hipoteza (3) zakłada związek między poziomem myślenia formalno-operacyjnego a poszczególnymi stylami tożsamości i zaangażowaniem $\mathrm{w}$ grupie adolescentów oraz jego brak w późniejszych okresach dorosłości. Hipoteza ta tylko częściowo została potwierdzona w przeprowadzonych przez nas badaniach. W grupie nastolatków zaobserwowano bowiem ujemny związek między wynikami w TOF a nasileniem stylu normatywnego i zaangażowania, a istotna, dodatnia, lecz słaba zależność wystąpiła między poziomem kompetencji formalno-operacyjnych a nasileniem zaangażowania $\mathrm{w}$ grupie seniorów. Są to jedyne korelacje rozpoznane po uwzględnieniu wszystkich grup wiekowych

Oznacza to, że wraz z opanowywaniem rozumowania hipotetyczno-dedukcyjnego młodzież łatwiej dostrzega słabe strony autorytetów, jest krytycznie do nich nastawiona i rzadziej niż ci, którzy nie posiadają tej sprawności poznawczej, buduje tożsamość, opierając się na zasadach i wzorcach pochodzących od autorytetów. Poza tym adolescenci, którzy posługują się rozumowaniem kombinatorycznym, wykorzystują te umiejętności do tworzenia różnorodnych modeli własnego życia i testowania wielu możliwości. Na tym etapie życia, w którym dominuje proces konstruowania idealistycznych koncepcji własnej przyszłości, nie ma więc miejsca na koncentrowanie się na określonych wartościach i celach, a tym bardziej na podejmowanie wysiłków w celu ich zrealizowania.

Istotna, aczkolwiek słaba korelacja między nasileniem zaangażowania a poziomem myślenia formalno-operacyjnego wyłoniła się u seniorów, co można wiązać z dokonywaniem bilansu życia i zogniskowaniem względnie wysokiej motywacji w realizację nielicznych już kierunków aktywności lub porządkowanie dotychczas realizowanych, niezbędnych do rozstrzygnięcia kryzysu integracja-rozpacz (Erikson, 1968; Niemczyński, 1980).

\section{ZAKOŃCZENIE}

Podsumowując kwestię zależności między stylami tożsamości a kompetencjami poznawczymi w zakresie operacji formalnych w różnych okresach rozwojowych, na podstawie prezentowanych badań zauważamy, że rozważane zdolności poznawcze testowane ,zadaniami piagetowskimi" u adolescentów związane są ze stylem normatywnym i poziomem zaangażowania $\mathrm{w}$ ten sposób, że osoby o wyższej sprawności rozumowania operacyjnego w procesie budowania koncepcji siebie i swojego życia rzadziej opierają się na wzorcach płynących od autorytetów i w mniejszym stopniu koncentrują się na realizacji konkretnych zadań rozwojowych, co można wiązać z fazą moratorium. W grupach młodych dorosłych i osób w średniej dorosłości nie wystąpiły istotne zależności między myśleniem formalno-operacyjnym a stylami tożsamości, co skłoniło nas do sformułowania dodatkowego pytania badawczego, na które obecnie szukamy odpowiedzi, prowadząc badania empiryczne, a które dotyczy zależności poziomu myślenia 
postformalnego ze stylami tożsamości. Skoro bowiem myślenie to $\mathrm{w}$ porównaniu $\mathrm{z}$ myśleniem formalno-operacyjnym pełni bardziej adaptacyjne funkcje w życiu człowieka dorosłego, to można oczekiwać że będzie też miało większe znaczenie w procesie budowania jego tożsamości. Dostępne wyniki badań pilotażowych zdają się potwierdzać zasadność tych poszukiwań, gdyż zależności pojawiają się u młodych dorosłych, gdy rozwijają się cechy myślenia postformalnego i są pozytywnie skorelowane ze stylem informacyjnym oraz zaangażowaniem, a negatywnie ze stylem dyfuzyjno-unikowym. Rozumowanie nastolatków ujawniające cechy myślenia postformalnego wiąże się z zaangażowaniem w podobny sposób jak myślenie formalno-operacyjne, czyli rodzące się zdolności uwzględniania wielu perspektyw, odkrywania różnorodnych możliwości, zarówno w zakresie rozwiązywania konkretnych praktycznych problemów, jak i zadań rozwojowych, utrudniają zaangażowanie adolescentów w określony kierunek aktywności, sprzyjając prawdopodobnie dalszym poszukiwaniom (moratorium).

Pojawienie się u młodych dorosłych cech myślenia postformalnego wiąże się z nasileniem stylu informacyjnego i zaangażowania oraz obniżeniem poziomu stylu dyfuzyjno-unikowego. Zdecydowanie większa siła związku ujawnia się w średniej dorosłości (pomimo małej liczby badanych) i dotyczy stylu informacyjnego oraz zaangażowania.

Odkryte zależności są spójne z wynikami badań Berzonsky'go (2008), który, odwołując się do koncepcji podwójnego przetwarzania informacji, rozpoznał powiązanie stylu tożsamości zarówno z myśleniem analitycznym, jak i intui- cyjnym. Analiza cech myślenia postformalnego: relatywizmu, dialektyczności, kontekstualizmu, systemowości pozwala sądzić, że reprezentują one obydwa wymienione sposoby przetwarzania informacji. Uwzględniając perspektywę temporalną (Trempała, 2000) oraz testowany w prezentowanym badaniu udział ,narzędzi poznawczych" w procesie budowania tożsamości przez adolescentów i osoby dorosłe, możemy stwierdzić, że:

- adolescenci opierają się na ideach, planach i wizjach przyszłego życia, a więc użyteczne w tym procesie mogą być operacje formalnego myślenia, aczkolwiek w naszych eksploracjach okazało się, że ograniczają rozwój stylu normatywnego i zaangażowania. Jednakże z perspektywy dalszego rozwoju młodzieży (jej autonomii) silne przywiązanie do autorytetów i koncentracja zaangażowania na wybranych zadaniach mogą ten rozwój utrudniać;

- w dorosłości, gdy tożsamość określana jest przede wszystkim na podstawie doświadczeń związanych z pełnieniem funkcji społecznych (rodzinnych, zawodowych czy obywatelskich) i celów zanurzonych w pragmatyce życia codziennego, większego znaczenia nabierają te rozumowania, które uwzględniają kontekst treściowy analizowanego zagadnienia, pozwalają integrować sferę zachowań, emocji i poznania oraz rozwijać metarefleksję, czyli rozumowania ogólnie określane jako postformalne.

Kolejne etapy rozpoczętego badania pozwolą nam ustosunkować się do tych interpretacji w kontekście wyników pochodzących od osób w wieku senioralnym.

\section{PRZYPISY}

${ }^{1}$ Pozycja epistemiczna (określana też jako wiedza epistemiczna) definiowana jest jako uogólniona metawiedza, która zawiera zarówno przekonania o naturze wiedzy (elementy deklaratywne), jak i dotyczące przebiegu poznania (elementy proceduralne) (Hofer, Pintrich, 1997).

${ }^{2}$ Formistyczne stanowisko epistemiczne zakłada istnienie w świecie z góry ustalonych uniwersalnych form lub typów (np. idee platońskie). Osoby, które wyznają ten pogląd, dążą do odkrycia istoty zjawisk przez identyfikację ich uniwersalnych typów. Według stanowiska konstruktywistycznego człowiek konstruuje wiedzę o świecie, która może się zmieniać w zależności np. od uwzględnianych kontekstów. 


\begin{abstract}
${ }^{3}$ Absolutyzm epistemiczny (Chandler, Boyes, Ball, 1990) charakteryzuje się poszukiwaniem źrodeł poglądów i ich ocen nie w umyśle poznającego, ale w rzeczywistym świecie na temat rzeczywistości. Postawa ewaluacyjna wyraża się w poglądzie, że poprawny sąd można wskazać, uwzględniając czynnik subiektywny (opinie czy gusta) i weryfikując go przez odniesienie do rzeczywistości.

${ }^{4}$ Teoria podwójnego procesu poznawczego (dual-processes theories) zakłada istnienie dwóch procesów poznawczych: intuicyjnego i analitycznego (racjonalnego). Intuicyjny system poznawczy pełni funkcje adaptacyjne dzięki temu, że działa szybko i automatycznie. Zabezpiecza to procesy przetwarzania informacji przed przeciążeniami, ale oparcie się wyłącznie na nim wiąże się z ryzykiem nieuwzględnienia wszystkich ważnych aspektów sytuacji problemowej. Jest użyteczny w powtarzających się niezbyt skomplikowanych przypadkach. System analityczny włączany jest wówczas, gdy nie można się skutecznie odwołać do sprawdzonego schematu rozwiązania, a także, gdy tych rozwiązań jest wiele. Działanie poznawczego systemu analitycznego polega na hamowaniu systemu intuicyjnego oraz na budowaniu oderwanych od kontekstu, ogólnych reprezentacji sytuacji problemowych (Evans, 2002).

${ }^{5}$ Potrzeba poznawczego domknięcia jest to proces strukturyzowania i upraszczania informacji w celu ułatwienia poradzenia sobie z jej nadmiarem (Kruglanski, 1989). Jest też traktowana jako stała tendencja wyznaczająca sposób naszego funkcjonowania w świecie (Kossowska, 2003).
\end{abstract}

\title{
BIBLIOGRAFIA
}

Arnett J.J. (2000), Emerging Adulthood: A Theory of Development from the Late Teens, Through the Twenties. American Psychologist, 55(5), 469-480.

Berzonsky M.D. (1981), Adolescent Development, New York: Macmillan

Berzonsky M.D. (1989), Identity Style: Conceptualization and Measurement. Journal of Adolescent Research, 4, 268-282.

Berzonsky M.D. (2003), Identity Style and Well-Being: The Role of Commitment. Identity: An International Journal of Theory and Research, 3(1), 131-142.

Berzonsky M.D. (2005), Ego Identity: A Personal Standpoint in a Postmodern World. Identity: An International Journal of Theory and Research, 5(2), 125-136.

Berzonsky M.D. (2008), Identity Formation: The Role of Identity Processing Style and Cognitive Processes. Personality and Individual Differences, 44(3), 645-655.

Berzonsky M.D. (2010), Cognitive Processes and Identity Formation: The Mediating Role of Identity Processing Style. Psychologia Rozwojowa, 15(4), 13-27.

Berzonsky M.D., Barclay C.R. (1981), Formal Reasoning and Identity Formation: A Reconceptualization. Contributions to Human Development, 5, 61-87.

Berzonsky M.D., Ferrari J.R. (1996), Identity Orientation and Decisional Strategies. Personality and Individual Differences, 20, 597-606.

Berzonsky M.D., Weiner A.S., Raphael D. (1975), Interdependence of Formal Reasoning. Developmental Psychology, 11(2), 258.

Boyes M., Chandler M. (1992), Cognitive Development, Epistemic Doubt, and Identity Formation in Adolescence. Journal of Youth and Adolescence, 21(3), 277-304.

Cacioppo J.T., Petty R.E., Feinstein J.A., Jarvis W.B. (1996), Dispositional Differences in Cognitive Motivation: The Life and Times of Individuals Varying in Need for Cognition. Psychological Bulletin, 119(2), 197-253.

Caputi P., Oades L. (2001), Epistemic Assumptions Understanding Self and the World (A Note on the Relationship Between Identity Style, World View, and Constructivist Assumptions: Using an Australian Sample). Journal of Constructivist Psychology, 14, 127-134.

Chandler M., Boyes M., Ball L. (1990), Relativism and Stations of Epistemic Doubt. Journal of Experimental Child Psychology, 50, 376-395.

Darmody J.P. (1991), The Adolescent Personality, Formal Reasoning, and Values. Adolescence, 26(103), 731-742.

Epstein S., Pacini R. (1999), Some Basic Issues Regarding Dual-Process Theories from the Perspective of Cognitive-Experiential Theory. W: S. Chaiken, Y. Trope (eds.), Dual-Process Theories in Social Psychology, New York: The Guildford Press, 462-482. 
Erikson E. (1968), Identity, Youth and Crisis. New York: W.W. Norton Company.

Evans Jonathan S.B.T. (2002), Logic and Human Reasoning: An Assessment of the Deduction Paradigm. Psychological Bulletin, 128(6), 978-996.

Gurba E. (1995), The Usefulness of Everyday Tasks to Measure Adults' Mental Abilities. Polish Quarterly of Developmental Psychology, 1(3), 185-194.

Gurba E. (2005), On the Specific Character of Adult Thought: Controversies over Post-Formal Operations. Polish Psychological Bulletin, 36(3), 175-185.

Gurba E. (2011), Wczesna dorosłość. W: J. Trempała (red.), Psychologia rozwoju człowieka. Warszawa: PWN, 287-312.

Gurba E. (2013), Nieporozumienia z dorastajacymi dziećmi w rodzinie. Uwarunkowania i wspomaganie. Kraków: Wydawnictwo Universytetu Jagiellońskiego.

Hannah M.T., Domino G., Figueredo A.J., Hendrickson R. (1996), The Prediction of Ego Integrity in Older Persons. Educational and Psychological Measurement, 56, 930-950.

Harker L., Solomon M. (1996), Changes in Goals and Values of Men and Women from Early to Mature Adulthood. Journal of Adult Development, 3, 133-143.

Hofer B.K., Pintrich P.R. (1997), The Development of Epistemological Theories: Beliefs about Knowledge and Knowing and Their Relation to Learning. Review of Educational Research Spring, 67(1), 88-140.

Kallio E. (2011), Integrative Thinking is the Key: An Evaluation of Current Research into the Development of Thinking in Adults. Theory \& Psychology, 21(6), 785-801.

Klaczynski P.A., Lavallee K.L. (2005), Domain-Specific Identity, Epistemic Regulation, and Intellectual Ability as Predictors of Belief-Based Reasoning: A Dual-Process. Journal of Experimental Child Psychology, 92(1), 1-24.

Kossowska M. (2003), Poznawcze mechanizmy radzenia sobie ze złożonością informacji. Przegląd Psychologiczny, 46(1), 37-55.

Kramer D.A. (1983), Post-Formal Operations? A Need for Further Conceptualization. Human Development, 26, 91-105.

Krettenauer T. (2005), The Role of Epistemic Cognition in Adolescent Identity Formation: Further Evidence. Journal of Youth and Adolescence, 34(3), 185-198.

Kroger J. (2007), Identity Development. London: Sage Publication.

Kruglanski A.W. (1989), Lay Epistemic and Human Knowledge: Cognitive and Motivational Bases. New York: Plenum.

Labouvie-Vief G. (1982), Dynamic Development and Mature Autonomy: A Theoretical Prologue. Human Development, 25, 161-191.

Longeot, F. (1985), Structures et fonctionnement cognitif a la lumière de l'analyse factorielle. Archives de Psychologie, 53, 465-467.

Marcia J.E. (1980), Identity in Adolescence. W: J. Adelson (ed.), Handbook of Adolescent Psychology. New York: Wiley, 109-137.

Mc Adams D.P. (2001), The Psychology of Life Stories. Review of General Psychology, 5(2), 100-122.

Michalska P. (2015), Rozumowanie sylogistyczne ludzi dorostych. Bydgoszcz: Wydawnictwo Uniwersytetu Kazimierza Wielkiego.

Niemczyński A. (1980), Modele indywidualnego rozwoju czlowieka. Kraków: Wydawnictwo Uniwersytetu Jagiellońskiego.

Njus D., Johnson D.R. (2008), Need for Cognition as Predictor of Psychosocial Identity Development. The Journal of Psychology, 142(4), 645-655.

Obuchowski K. (1977), Autonomia jednostki a osobowość. W: J. Reykowski, T. Owczynnikowa, K. Obuchowski (red.), Studia z psychologii emocji, motywacji i osobowości, 77-101. Wrocław: Ossolineum.

Olejnik M. (2011), Średnia dorosłość. W: J. Trempała (red.), Psychologia rozwoju człowieka, 312-323, Warszawa: PWN.

Oleszkowicz A., Senejko A. (2013), Psychologia dorastania. Warszawa: PWN

Oleś P. (2011), Psychologia człowieka dorosłego. Warszawa: PWN.

Papini D.R., Sebby R.A. (1987), Adolescent Pubertal Status and Affective Family Relationships: A Multivariate Assessment. Journal of Youth and Adolescence, 16, 1-15. 
Piaget J. (1972), Intellectual Evolution from Adolescence to Adulthood. Human Development, 15, 1-12.

Salthouse T.A. (2009), When Does Age-Related Cognitive Decline Begin? Neurobiological Aging, 30(4), 507-514.

Sebby, R. A., Papini, D. R. (1994), Post-Formal Reasoning During Adolescence and Young adulthood: The Influence of Problem Relevancy. Adolescence, 29, 389-400.

Staudinger U.S., Bluck S., Herzberg P.Y. (2003), Back and Looking Ahead: Adult Age Differences in Consistency Diachronous Ratings of Subjective Well-Being. Psychology and Aging, 18(1), 13-24.

Trempała J. (2000), Modele rozwoju psychicznego. Czas i zmiana. Bydgoszcz: Wydawnictwo Uczelniane AB.

Wagner J.A. (1987), Formal Operations and Ego Identity in Adolescence. Adolescence, 22, 23-35. 